\title{
MAJAS DALAM ACARA TALKSHOW MATA NAJWA EPISODE \#MATANAJWAMENANTITERAWAN : KAJIAN LINGUISTIK TERAPAN
}

\author{
Putri Indah Yanti ${ }^{1}$, Bambang Yulianto ${ }^{2}$ \\ Pendidikan Bahasa dan Sastra \\ Universitas Negeri Surabaya, Surabaya, Indonesia \\ email: putriyanti31@gmail.com¹, bambangyulianto@unesa.ac.id ${ }^{2}$
}

\begin{tabular}{|l|c|c|}
\hline CC) () & \multicolumn{3}{|c|}{$\begin{array}{l}\text { This is an open-access article under the CC BY-SA license. } \\
\text { Copyright }(2021 \text { by Author. Published by Universitas Pendidikan Ganesha. }\end{array}$} \\
\hline Received : January, 2021 & Accepted : May, 2021 & Published : June, 2021 \\
\hline
\end{tabular}

\begin{abstract}
ABSTRAK
Pengungkapan gagasan menggunakan gaya bahasa/bahasa kias (majas) pada acara talkshow biasanya bertujuan untuk membangkitkan suasana tegang dan tanggapan beragam di antara penonton, selain untuk memperindah tuturan. Ini artinya majas tidak hanya diterapkan dalam kegiatan bersastra, melainkan juga dibutuhkan pada aspek-aspek terapan sehingga akan tercipta kondisi dan atau situasi yang diharapkan. Penelitian ini menggunakan metode deskriptif kualitatif karena data yang dikumpulkan berupa tuturan-tuturan Najwa Shihab yang menggunakan banyak bahasa kias (majas) sehingga perlu dianalisis secara mendalam untuk mengetahui maksud dan tujuannya. Objek penelitian ini adalah lima tuturan Najwa Shihab dalam Acara Talkshow Mata Najwa Episode \#MataNajwaMenantiTerawan yang berwujud pertanyaan yang ditujukan kepada Menteri Kesehatan RI, Terawan Agus Putranto yang diunggah pada kanal YouTube Mata Najwa pada tanggal 28 September 2020. Hasil penelitian ini menunjukkan bahwa pertanyaan-pertanyaan yang dilontarkan pemandu acara talkshow Mata Najwa, Najwa Shihab kepada Menteri Kesehatan RI, Terawan Agus Putranto dalam episode \#MataNajwaMenantiTerawan mengandung majas yang bervariasi, yakni majas ironi, repetisi, paradoks, alegori, dan sinisme. Dari kelimanya, bisa disimpulkan bahwa majas sindiranlah yang mendominasi pertanyaan-pertanyaan Najwa Shihab pada episode tersebut yang penggunaannya difungsikan untuk mengubah perilaku seseorang/sasaran.
\end{abstract}

Kata kunci: Mata Najwa, MataNajwaMenantiTerawan, majas

\section{ABSTRACT}

Expression of ideas using language style (figure of speech) aims to evoke a certain atmosphere and certain responses, in addition to beautifying speech. Thus, if figure of speech is applied not only in literary activities, but also in applied aspects, the expected situation conditions will be created. This research uses descriptive qualitative research methods. Descriptive research is carried out because the data collected for research is in the form of information containing research documentation and the data obtained needs to be analyzed in depth in order to get a detailed picture of the things that support the research. The object of this research is the spoken language spoken by Najwa Shihab in the Mata Najwa Talkshow Episode \#MataNajwaMenantiTerawan which was uploaded on the Mata Najwa YouTube channel on September 28, 2020 with more than six million viewers. Based on the results of this study, it is known that the questions asked by the talk show host Mata Najwa, Najwa Shihab to the Minister of Health, Terawan Agus Putranto in the episode \#MataNajwaMenantiTerawan contain various figures, namely irony, repetition, paradox, allegory, and cynicism. From the five, it can be concluded that satirical figure of speech dominate Najwa Shihab's questions in the episode whose use is used to change a person's / target's behavior. 
Keywords:Mata Najwa, MataNajwaMenantiTerawan, majas

\section{PENDAHULUAN}

Bahasa merupakan unsur yang tidak dapat dipisahkan dengan manusia dalam kehidupan kesehariannya. Dalam melakukan aktivitasnya, manusia tidak terlepas dari menggunakan bahasa. Hampir semua aspek yang terlibat dalam kehidupan manusia selalu membutuhkan kehadiran bahasa, termasuk dalam aspek hiburan, baik hiburan secara langsung maupun yang tidak langsung, seperti di televisi. Akan tetapi, dewasa ini, penggunaan bahasa dalam dunia hiburan mulai bergeser. Jika dulu penggunaan bahasa hampir selalu disimpangkan demi menimbulkan efek kelucuan, maka kini hal tersebut tidak berlaku lagi sepenuhnya. Bahkan, penyimpangan-penyimpangan bahasa kian marak dilakukan dalam dunia pertelevisian Indonesia guna memunculkan daya tarik penonton sehingga membuat penonton merasa kecanduan terhadap suatu acara karena gaya bahasa yang dimunculkan dan berpeluang menjadi ciri khas dari acara tersebut.Value yang sengaja ditampilkan oleh suatu acara tertuang secara sengaja melalui bentuk komunikasi yang dibangun dengan membawa maksud dan tujuan tertentu sesuai dengan permintaan. Komunikasi menjadi sebuah proses pernyataan yang di dalamnya terdapat pikiran serta perasaan seseorang kepada orang lain dengan menggunakan bahasa sebagai alat penyalurannya. Melalui komunikasi, manusia dapat saling mengungkapkan pikiran (Kayati, 2020). Pengungkapan pikiran melalui komunikasi adalah hal yang pasti terjadi, oleh karenanya, penyimpangan dan penerapan gaya bahasa menjadi lahan basah yang harus terus digali demi menarik minat penonton lebih banyak.

Pikiran yang diungkapkan melalui komunikasi sangat bermacam-macam, mulai dari pemikiran empiris dan kritis sampai yang remeh-temeh. Lebih daripada itu, komunikasi yang digunakan pun juga variatif, baik komunikasi dua arah maupun satu arah. Dalam bahasa, aktivitas komunikasi disesuaikan dengan latar sosial dan hubungan peserta komunikasi (Ningsih, dkk., 2019). Jadi dalam hal ini, komunikasi memiliki aturan terkait lokasi dan tempat penerapannya dan dengan siapa komunikasi tersebut berlangsung. Sebab, ini akan berhubungan dengan gaya bahasa yang akan dipakai. Meski demikian, aktivitas berbahasa dalam konteks komunikasi tetap menjadi hak masing-masing orang. Pernyataan ini diperkuat oleh pendapat yang mengatakan bahwa bahasa dapat digunakan oleh siapa saja, dimana saja, dan kapan saja (Kartikasari, 2016). Artinya, tidak ada ketentuan yang mengatur di mana, kapan dan siapa yang terlibat dalam sebuah aktivitas berbahasa. Apabila ada pendapat-pendapat yang menghubungkan aktivitas berbahasa tersebut dengan gaya bahasa yang akan dipakai, ini merupakan sebuah anjuran dan tidak bersifat mutlak, sebab komunikasi menjadi wewenang yang bersangkutan, meski tetap harus sesuai dengan koridor norma-norma yang berlaku.

Mengingat peran komunikasi yang bersifat fundamental, oleh karena itu komunikasi dapat dijadikan sebagai alat menyampaikan gagasan dan pemikiran dengan berbagai variasi yang membersamainya. Bahkan, penyampaian gagasan atau pemikiran dapat dimudahkan dengan kehadiran perkembangan teknologi saat ini, yang memungkinkan komunikasi jarak jauh bisa berlangsung dengan bantuan internet dan media sosial. Dengan adanya internet akses komunikasi dan berbagi informasi menjadi 
sangat mudah sehingga hal ini berpotensi untuk mengubah pola komunikasi antar manusia di banyak lini kehidupan, salah satunya bidang jurnalis dan media (Adiba, 2018). Media-media informasi, baik cetak, elektronik, maupun sosial, dewasa ini menggunakan gaya bahasa yang khas dan mengandung keingintahuan yang kuat yang tentu akan menjadi daya tarik untuk pembacanya. Tidak hanya pada judul yang ditulis, melainkan bahasa pembawa beritanya pun juga turut memperlihatkan adanya keunikan yang menjadi ciri khusus dari suatu media informasi, satu di antaranya yakni media informasi elektronik berbasis internet, kanal YouTube acara talkshow Mata Najwa yang dipandu oleh jurnalis muda nan kritis bernama Najwa Shihab. Acara yang dipandu oleh putri ulama kondang, Qurraish Shihab ini sangat menyita perhatian publik, selain telah memiliki penonton setia yang cukup banyak (dibuktikan dengan jumlah subscriber lebih dari 6 juta), gaya dan aksen bahasa yang digunakan Najwa dalam membawakan acaranya pun menuai cukup banyak polemik, sebab ia sudah beberapa kali dilaporkan ke kepolisian karena bahasa yang digunakan sangat nyentrik dan cenderung mengandung majas yang multipersepsi.

Majas termasuk ke dalam pemilihan kata yang akan diungkapkan secara lisan maupun tulisan agar terkesan lebih indah dan menarik. Majas tidak hanya digunakan pada sebuah karya sastra untuk menunjang keindahan, namun majas juga dapat digunakan sebagai mediasi dalam menyampaikan gagasan dan pemikiran setiap individu. Gaya berbahasa atau majas yang digunakan oleh seseorang tidak sama dengan majas yang digunakan oleh orang lain (Rani, 2018). Hal ini disebabkan setiap individu memiliki karakteristik yang berbeda. Perilaku serta pengalamannya akan mempengaruhi gaya berbahasanya. Secara tidak langsung, pengalaman dan masa lalu seseorang juga mempengaruhi majas apa yang cenderung sering dipakai dalam penggunaan bahasanya. Sehingga hal menyangkut gaya bahasa individu ini tidak sebagai sebatas ujaran, melainkan juga terhubung dengan pengalaman-pengalaman yang ada dipikiran. Dengan kata lain, apabila dilakukan analisis mendalam, dari majas yang dipakai seseorang, dapat diketahui bagaimana pengalaman yang pernah dilalui dan lingkungan yang membentuk gaya bahasanya. Sejalan dengan pendapat di atas, dalam Muamanah, dkk (2019), Keraf mengemukakan bahwa majas berkaitan dengan bagaimana seseorang menggunakan ketepatan dalam mengungkapkan sesuatu; keefektifan struktur kalimat; penggunaan bahasa kiasan yang serasi; penampilan yang sesuai dengan situasi; dan lain sebagainya. Pernyataan Keraf menegaskan kembali, bahwa bahasa seseorang mempengaruhi banyak sisi dari kehidupan.

Menurut Orecchioni (dalam Zaimar, 2002), semua jenis makna yang mengandung implisit dalam konteks tertentu dapat membentuk kehadiran majas. Majas dianggap sebagai suatu kasus khusus dari fungsi implisit (metafora, metonimi, sinekdoke, litotes, ironi, dan lain-lain). Dalam majas, bentuk yang implisit bersifat denotatif dan bentuk yang menggantikannya bersifat konotatif. Menurutnya, majas dipisahkan dalam beberapa kelompok, yakni majas pertentangan, majas perbandingan, majas sindiran, dan majas penegasan. Dari empat kelomppok tersebut, jumlah majas cukup banyak sebagai berikut : majas repetisi, pleonasme, personifikasi, hiperbola, metafora, simile, antitesis, asosiasi, alegori, simbolik, metonimia, sinekdok, paradoks, litotes, ironi, sinisme, dan sarkasme. Repetisi atau yang biasa disebut dengan pengulangan merupakan suatu majas yang menekankan pada seluruh kata (bentuk lain) yang diulang. Pengulangan ini dapat berupa satu kata saja, satu frase, satu klausa, atau satu kalimat. Pleonasme merupakan pengulangan dengan penanda yang berbeda. 
Komponen makna yang terdapat pada kata pertama, telah tercakup dalam wilayah makna kata (bentuk lain) berikutnya. Pada pembahasan mengenai majas simile, terdapat dua kata (bentuk lainnya) yang masing-masing menampilkan konsep dan acuan yang berbeda. Sehingga antara satu kata dengan kata lainnya dapat dibandingkan. Perbandingan tersebut tentunya tidak memunculkan masalah. Majas ini mudah dikenali, karena kedua penanda muncul secara bersamaan dan selalu dihubungkan oleh kata pembandingnya. Majas selanjutnya, metafora, dibentuk berdasarkan penyimpangan makna. Dalam metafora terdapat dua bentuk bahasa (penanda) yang maknanya diperbandingkan. tetapi salah satu unsur bahasa yang dibandingkan itu tidak muncul, melainkan bersifat implisit. Sifat implisit ini menyebabkan adanya perubahan acuan pada penanda yang digunakan. Selain itu, tidak ada kata yang menunjukkan perbandingan seperti dalam simile. Metafora sering dianggap sebagai bentuk majas terpenting, beberapa pakar linguistik mengelompokkan beberapa jenis majas lain ke dalam metafora. Selanjutnya, majas personifikasi sering dimasukkan ke dalam majas metafora, karena penjelasannya secara semantik sama. Personifikasi adalah majas yang menampilkan binatang, tanaman, atau benda sebagai manusia. Antitesis adalah oposisi antara dua gagasan dengan menggunakan dua leksem atau frase yang disandingkan agar lebih jelas dan menonjol kontrasnya. Kedua leksem mengandung makna yang berlawanan dan keduanya muncul bersama, jadi tidak bersifat implisit. Serupa tapi tak sama, paradoks adalah opini atau argumen yang berlawanan dengan pendapat pada umumnya. Opini ini dapat dianggap aneh atau luar biasa. Dikatakan juga paradoks, suatu proposisi yang salah tetapi sekaligus juga benar. Sering kali di balik gagasan yang mengherankan, paradoks menyembunyikan kebenaran yang dapat dipertahankan. Dalam majas ini, ada dua penanda yang mempunyai makna yang beroposisi. Kedua penanda muncul, jadi tidak bersifat implisit. Namun, oposisi itu ada dalam makna kata saja, sedangkan di dalam kehidupan seringkali paradoks itu tidak merupakan oposisi melainkan menguatkan makna.

Dalam kelompok majas sindiran, ada majas ironi, dalam pengertian ini pengujar menyampaikan sesuatu yang sebaliknya dari apa yang ingin dikatakannya, jadi di sini terdapat satu penanda dengan dua kemungkinan petanda. Ironi mengandung antonimi atau oposisi antara kedua tataran isi. Ironi juga mengandung kesenjangan yang cukup kuat antara makna harfiah dengan makna kiasan. Maka di dalam ironi terdapat keharusan yang sering bertumpu pada makna inversi semantis, baik secara keseluruhan maupun sebahagian. Hal ini menjadi ciri ironi. Apabila dilihat dari wilayah maknanya, ironi tidak banyak berbeda dengan majas pertentangan lainnya. Namun dalam ironi salah satu bentuk (penanda) tidak hadir, jadi bersifat implisit. Perlu diingat bahwa pemahaman ironi sangat tergantung dari konteks (bahkan beberapa ahli bahasa membedakan ironi dari majas lainnya, karena hal tersebut). Apabila konteks tidak mendukung ironi, maka ujaran yang mengandung ejekan dapat menjadi pujian. Dalam metonimi, pada awalnya, bukan komponen makna yang berperan melainkan perubahan acuan. Metonimi berlandaskan hubungan kontiguitas yang berarti hubungan ekstern. Penanda dapat ditransfer berkat adanya kontiguitas acuan. Artinya, penanda tertentu dapat digunakan untuk mengemukakan suatu petanda yang lain, berkat adanya kontiguitas (kedekatan) acuan di antara kedua tanda. Bila dalam metafora ada pertemuan atau persilangan makna, maka dalam metonimi terdapat ketercakupan atau kepemilikan bersama keseluruhan makna. Contoh: penanda /honda/ dapat mempunyai petanda manusia (yang memiliki perusahaan), perusahaan yang menghasilkan mobil / 
motor atau benda yang dihasilkan, yaitu mobil / motor itu. Seperti dalam metafora, di sini juga terjadi penyimpangan makna, hanya saja dasarnya berbeda. Apabila dalam metafora dasar penyimpangan itu adanya komponen makna penyama pada kedua leksem, maka dalam metonimi yang menjadi landasan adalah hubungan kontiguitas acuan.

Setali tiga uang, dalam sinekdoke bukan hanya komponen makna yang berperan melainkan juga hubungan antar acuan. Penanda dari leksem pertama dapat ditransfer ke leksem kedua berkat adanya komponen makna penyama. Selain itu, makna yang dimiliki oleh petanda tertentu dengan acuan tertentu dapat digunakan untuk mengemukakan suatu petanda lain dengan acuan yang lain pula, berkat adanya hubungan antar acuan. Dalam sinekdoke, kedekatan acuan itu disebabkan karena acuan yang pertama merupakan bagian dari acuan yang kedua (pars prototo) atau acuan yang pertama mencakup acuan yang kedua (totem proparto). Dapat dikatakan bahwa perpindahan makna sinekdoke berdasarkan adanya komponen makna penyama. Hiperbola adalah ucapan (ungkapan, pernyataan) kiasan yang dibesar-besarkan (berlebih-lebihan), dimaksudkan untuk memperoleh efek tertentu, bukan yang sebenarnya. Kata ini berasal dari bahasa Yunani, dan berarti "kesederhanaan". Berbeda dengan hiperbola, majas ini digunakan untuk melemahkan ungkapan pikiran, jadi untuk menampilkan gagasan tentang sesuatu yang kuat atau besar dengan ungkapan yang lemah. Ungkapan yang dihaluskan dalam mengemukakan suatu gagasan. Hal ini dilakukan apabila ungkapan gagasan tersebut secara langsung, bisa menimbulkan perasaan yang tidak enak, atau terasa agak kasar.

Pengungkapan gagasan menggunakan gaya bahasa/bahasa kias (majas) bertujuan untuk membangkitkan suasana tertentu dan tanggapan tertentu, selain untuk memperindah tuturan (Santoso, 2016). Dengan demikian, apabila majas diterapkan tidak hanya dalam aktivitas kesusasteraan, melainkan juga pada aspek-aspek terapan maka akan bisa diciptakan kondisi situasi yang diharapkan, oleh sebab itu, pendapat Santoso tersebut diperkuat dengan pernyataan bahwa bentuk pengungkapan gagasan menggunakan bahasa kias (majas) sudah banyak diterapkan di masyarakat (Nurgiyantoro, 2015). Dari beberapa pendapat dan uraian di atas bisa diketahui bahwa keterlibatan gaya bahasa/majas dalam aktivitas komunikasi (baik satu arah maupun dua arah) berpengaruh dan berpotensi membentuk stigma dan suasana yang akan dikehendaki oleh komunikan.

\section{METODE}

Penelitian ini menggunakan rancangan penelitian deskripstif kualitatif. Metode penelitian kualitatif melalui pengumpulan dan penganalisisan data berupa kata-kata, baik secara lisan maupun tulisan, sehingga peneliti tidak perlu menghitung dan mengkuantifikasikan data kualitatif yang telah diperoleh (Afrizal, 2016), oleh karena itu hasil penelitian ini berupa pernyataan-pernyataan deskriptif mengenai variasi majas yang ditemukan.

Objek penelitian ini adalah lima tuturan pertanyaan Najwa Shihab dalam acara talkshow Mata Najwa di stasiun televisi Metro TV Episode \#MataNajwaMenantiTerawan yang ditujukan kepada Menteri Kesehatan RI, Terawan Agus Putranto yang tidak dapat hadir pada acara tersebut sehingga Najwa Shihab melontarkan pertanyaan itu kepada kursi kosong. Oleh karena itu, episode ini sangat viral di media (baik elektronik, cetak, maupun sosial) dan dikenal dengan video Mata Najwa Kursi Kosong. 
Episode ini juga diunggah pada kanal YouTube Mata Najwa pada tanggal 28 September 2020 dan sampai penelitian ini ditulis, video tersebut telah ditonton lebih dari enam juta penonton.

Data pada penelitian ini berupa transkrip tuturan pertanyaan-pertanyaan Najwa Shihab yang berisi majas-majas selama acara berlangsung. Sedangkan sumber data merupakan benda, orang, atau pihak yang dipandang dapat memberi informasi dan menjadi asal-muasal hal-hal yang berkaitan dengan penelitian (sumber informasi). Sumber data yang digunakan pada penelitian ini adalah kanal YouTube Mata Najwa, khususnya pada video Mata Najwa Episode \#MataNajwaMenantiTerawan.

Pada peneltian ini teknik pengumpulan data yang dilakukan adalah dengan menggunaka metode simak. Simak dianggap memiliki kesesuain dengan data penelitian yang berupa tuturan. Simak dilakukan secara berulang-ulang terhadap rekaman video yang mengandung tuturan Najwa Shihab, untuk mengamati dan melihat keteraturan penggunaan bahasa yang diteliti. Metode ini hampir sama dengan metode pengamatan atau metode observasi dalam ilmu-ilmu sosial. Proses penyimakan dalam metode simak ini dilakukan dengan cara penyadapan. Dalam hal ini, seorang peneliti dengan segenap kemampuannya melakukan penyadapan terhadap bahasa yang digunakan dalam komunikasi penutur suatu bahasa baik berupa pembicaraan seorang (monolog), berpasangan, atau beberapa orang (dialog). Teknik sadap dipandang sebagai teknik dasar dalam metode simak. Dalam teknik dasar, peneliti melakukan kegiatan menyimak serta memantau komunikasi terhadap Angga Praja Buana dengan beberapa pasien yang sedang diobati. Setelah melakukan aktivitas menyimak dan memantau, dilanjutkan dengan teknik lanjutan. Teknik lanjutan ini dapat digunakan berdasarkan teknik dasar yang telah digunakan. Pada penelitian ini, teknik lanjutan yang digunakan adalah teknik Simak Bebas Libat Cakap (SBLC). Teknik simak bebas libat cakap ini dilakukan dengan menyadap tanpa perlu berpartisipasi berbicara. Peneliti tidak ikut dalam proses pembicaraan. Peneliti hanya sebagai penyimak yang penuh minat tekun mendengarkan apa yang dikatakan oleh orang-orang yang berbicara.

Dari menyimak data, dalam episode tersebut sebenarnya ada sepuluh pertanyaan yang dilontarkan Najwa Shihab kepada Terawan Agus Putranto, namun hanya lima pertanyaan yang mengandung majas. Pertanyaan-pertanyaan lainnya merupakan pertanyaan eksplisit, yang jelas, tajam, terarah dan tidak multi persepsi. Setelah data disimak berulang-ulang, diperoleh gambaran umum mengenai variasi majas yang digunakan dalam tuturan Najwa Shihab episode \#MataNajwaMenantiTerawan sebanyak lima jenis majas yang muncul, yakni majas ironi, repetisi, paradoks, alegori, dan sinisme. Kelima jenis majas yang muncul tersebut tergolong dari varian yang berbeda-beda. Majas ironi dan sinisme termasuk majas sindiran. Majas sindiran digunakan sebagai bentuk ekspresi ketidaksukaan terhadap sesuaatu dengan bantuan bahasa kiasan untuk meningkatkan efek atau pengaruhnya terhadap pendengar. Majas repetisi termasuk majas penegasan, yang menggunakan kata berulang untuk menonjolkan suatu maksud. Pengulangan kata yang dipakai berbentuk macam-macam bergantung kebutuhan. Majas paradoks termasuk majas pertentangan, yang menggunakan kata-kata kiasan untuk tujuan mempertentangkan suatu hal atau benda dengan benda lain agar menimbulkan suatu efek yang diharapkan, dan majas terakhir yang ditemukan adalah majas alegori, yang termasuk ke dalam majas perbandingan, yakni majas yang menautkan satu dan yang lainnya dalam kesatuan yang utuh. 


\section{PRASI JURNLL BAHASA, SEN, DAN PENGGARARWYA}

VOL. 16 | No. 01 | Juni 2021

ISSN: Print 1693-6124 - Online 2614-1116

Undiksha| DOI: http://dx.doi.org/10.23887/prasi.v16i01.31537 | https://ejournal.undiksha.ac.id/index.php/PRASI

Keterangan :

Nomor data : $1-5$

Tuturan : T

Konteks : K

Tabel 1. Pengolahan Data

\begin{tabular}{|c|c|c|c|c|}
\hline No & Data Penelitian & Tuturan & Konteks & Keterangan \\
\hline & Pertanyaan 1 & $\begin{array}{l}\text { Menteri kesehatan paling low } \\
\text { profile di seluruh dunia } \\
\text { selama wabah ini hanya } \\
\text { menteri kesehatan Republik } \\
\text { Indonesia }\end{array}$ & $\begin{array}{l}\text { Mengapa } \\
\text { menghilang, Pak? }\end{array}$ & T1K1 \\
\hline & Pertanyaan 2 & $\begin{array}{l}\overline{\text { Disaat negara-negara lain }} \\
\text { bahkan sudah berangsur- } \\
\text { angsur bisa memperlonggar } \\
\text { situasi, Pak. Kenapa kita } \\
\text { tertinggal? }\end{array}$ & $\begin{array}{l}\text { Pak Terawan, } \\
\text { sampai sekarang } \\
\text { kondisi pandemi } \\
\text { belum juga } \\
\text { terkendali }\end{array}$ & $\mathrm{T} 2 \mathrm{~K} 1$ \\
\hline & Pertanyaan 3 & $\begin{array}{l}\text { Kenapa tes kita belum } \\
\text { mencapai target? Kenapa } \\
\text { resapan anggaran } \\
\text { kementerian masih rendah? } \\
\text { Kenapa berbagai peraturan } \\
\text { dan birokrasi masih berbelit di } \\
\text { kementerian kesehatan? Dan } \\
\text { kenapa perlindungan tenaga } \\
\text { kesehatan kita belum } \\
\text { maksimal? }\end{array}$ & $\begin{array}{l}\text { Presiden Jokowi } \\
\text { secara terbuka } \\
\text { berulang kali } \\
\text { menegur kinerja } \\
\text { anda di depan } \\
\text { publik }\end{array}$ & T3K1 \\
\hline & Pertanyaan 4 & $\begin{array}{l}\text { Masih saja ada disparitas } \\
\text { antara data pusat dan data } \\
\text { daerah }\end{array}$ & $\begin{array}{l}\text { Mengapa sampai } \\
\text { sekarang juga } \\
\text { tidak beres? }\end{array}$ & T4K1 \\
\hline & Pertanyaan 5 & $\begin{array}{l}\text { Apakah penanganan kita lebih } \\
\text { baik dari negara yang } \\
\text { menkesnya mundur itu? }\end{array}$ & $\begin{array}{l}\text { Pak Terawan, ada } \\
\text { banyak menteri } \\
\text { kesehatan yang } \\
\text { mundur karena } \\
\text { penanganan } \\
\text { covid-19 misalnya } \\
\text { menteri kesehatan } \\
\text { New Zealand, } \\
\text { Ceko, Polandia, } \\
\text { Brazil, Chile, } \\
\text { Pakistan, Israel } \\
\text { publik health } \\
\text { director-nya } \\
\text { mundur, Canada } \\
\text { publik health } \\
\text { agency president- } \\
\text { nya mundur }\end{array}$ & T5K1 \\
\hline
\end{tabular}

\section{HASIL DAN PEMBAHASAN}

Penelitian ini dilakukan untuk mengetahui jenis-jenis majas pada tuturan berwujud pertanyaan-pertanyaan Najwa Shihab sebagai pemandu dalam acara 
talkshow Mata Najwa pada episode \#MataNajwaMenantiTerawan. Jenis majas yang digunakan Najwa Shibab pada episode ini ada lima, yaitu majas ironi, repetisi, alegori, sinisme, dan paradoks. Dari kelima majas tersebut, dua di antaranya adalah majas sindiran (ironi dan sinisme), kedua majas ini terkandung dalam pertanyaan Najwa Shihab ke-1 dan 5. Sedangkan majas lainnya tersebar dari majas penegasan, perbandingan, dan pertentangan. Berdasarkan jumlah data tersebut, maka dapat diketahui bahwa majas yang paling banyak dan lebih dominan ditemukan dalam tuturan Najwa Shihab adalah majas sindiran. Majas sindiran merupakan majas yang ditujukan untuk menyindir pendengar atau pembacanya. Majas ini bertujuan untuk mengubah perilaku seseorang (Anggraini dkk, 2019). Dengan demikian, ini artinya episode tersebut disiarkan dengan mengusung tujuan menyindir seseorang, jika benar, maka bisa jadi orang yang disindir itu adalah seseorang yang hendak dijadikan sasaran pertanyaan, yakni Menteri Kesehatan RI, Terawan Agus Putranto yang tidak hadir dalam acara tersebut. Namun, guna membuktikan dugaan dari kutipan di atas, masih perlu dilakukan penelitian lanjutan. Berikut merupakan kelima data penelitian yang diolah sehingga didapatkan tuturan dan konteksnya yang tertuang dalam tabel 1.

\section{Pertanyaan 1 (Majas Ironi)}

"Mengapa menghilang, Pak? Anda minim sekali muncul di depan publik memberikan penjelasan selama pandemi. Rasanya menteri kesehatan paling low profile di seluruh dunia selama wabah ini hanya menteri kesehatan republik indonesia?" (1.00-1.11)

Kutipan di atas mengandung majas ironi yang ditandai dengan kalimat bergaris bawah. Kalimat bergaris bawah pada pertanyaan 1 yang menganggap bahwa Menteri Kesehatan RI, Terawan Agus Putranto adalah menteri paling low profile adalah suatu hal yang memicu perdebatan. Sebab, dari sudut pandang pertanyaan 1 secara utuh, Menteri Kesehatan adalah satu-satunya menteri yang paling dibutuhkan untuk muncul ke depan publik, entah memberikan penjelasan, himbauan, klarifikasi atau pemberitahuan terkait dengan pandemi covid-19 yang sampai sekarang masih berlangsung. Tentu kehadiran Menteri Kesehatan adalah hal yang paling ditunggutunggu, sebab ia dianggap paling bertanggung jawab dalam hal penanganan pandemi. Sama seperti negara lain, pandemi covid-19 menjadi wadah bagi MenKes (atau pejabat setingkat) untuk unjuk gigi dalam memperlihatkan "kehebatannya" mengusir pandemi yang saat ini sedang menjadi masalah utama bagi seluruh masyarakat Indonesia. Akan tetapi, di awal kalimat pertanyaan 1, Najwa Shihab sudah memberi pembuka, "Mengapa menghilang, Pak?", nah dari potongan kalimat di atas, tentu semua yang mendengar ujaran tersebut akan berspekulasi, bahwa selama pandemi, Menteri Kesehatan (yang dianggap menjadi garda depan pemangku kebijakan penanganan kesehatan/pandemi) tidak muncul di publik. Jika memang benar demikian faktanya, tentu penggunaan kata low profile menjadi sangat bertolak belakang dengan kalimat, "mengapa menghilang, pak?". Namun, jika arti dari kata low profile disimpangkan dari "rendah hati karena tidak suka muncul di publik" menjadi "rendah hati karena tidak mau muncul di publik" maka ini menjadi pembuktian bahwa Menteri Kesehatan RI sedang disindir secara halus melalui ungkapan majas ironi. 
$\mathrm{T} 1$ : menteri kesehatan paling low profile di seluruh dunia selama wabah ini hanya menteri kesehatan republik Indonesia

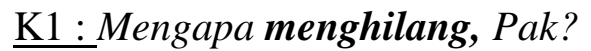

Kata low profile menjadi kunci dan ia tidak mengandung makna denotasi, melainkan sebaliknya, sebab sangat terkait dengan kata "menghilang" yang merupakan konteks dan unsur pendukung dari kata tersebut. Ungkapan ini jelas-jelas menunjukkan sebuah sindiran yang disampaikan secara halus, yang menggunakan majas ironi sebagai bentuk pengekspresiannya. Ketidakmunculan beliau ke publik (menghilang) tentu akan berujung panjang. Karena ketidakmunculannya, bisa jadi masyarakat akan menggangap bahwa MenKes tidak sedang "bekerja" menangani pandemi. Seolah-olah beliau dianggap lepas tangan, karena adanya penggunaan kata "menghilang" pada kalimat pertanyaan 1. Ketika kata "menghilang" ini dikaitkan dengan potongan kalimat selanjutnya yang menyatakan "menteri kesehatan paling low profile selama pandemi", jelas terbukti bahwa kata "low profile" pada konteks ini tidaklah mengandung arti sebenarnya, justru ini adalah suatu sindiran bagi Menkes, saking jarangnya muncul sehingga dianggap low profile, padahal situasinya, semua lini masyarakat membutuhkan kehadiran beliau. Dari hal ini bisa diketahui bahwa pertanyaan 1 merupakan pertanyaan yang mengandung majas sindiran, yakni majas ironi. Ironi dapat dikatakan sebagai praktik kepura-puraan karena menyembunyikan makna sebenarnya (Rani, 2018). Makna yang dimaksud berlawanan dengan apa yang dikatakan. "Kepurapuraan" inilah yang ditunjukkan Najwa Shihab selaku pemandu acara untuk mempublikasikan kepada khalayak luas dan menunggu Menkes Terawan untuk mengklarifikasi. Kata "low profile" menjadi kunci utama yang menegaskan pertanyaan ini menggunakan majas ironi. Low profile dalam bahasa Inggris diartikan sebagai sikap orang yang rendah hati, yang tidak suka menampakkan kehebatannya di depan umum. Penggunaan kata "low profile" seolah-olah dianggap mewakili Menteri Terawan yang sangat jarang muncul di depan publik guna menampilkan kebijakan-kebijakannya terkait penanganan pandemi, padahal ia memiliki wewenang khusus terhadap permasalahan ini. Namun, karena intensitas kemunculan beliau di publik sangat rendah, dan tidak tampak gerakan-gerakan penanganan bersumber dari beliau, sehingga Najwa Shihab memilih diksi "low profile" untuk mewakili sikap Menteri Terawan yang no policy, no publicity. Namun rupanya, dalam konteks pertanyaan ini, diksi "low profile" tidak dimaknai sebenarnya. Keberadaan diksi ini hanyalah sebagai sindiran terhadap ketidakmunculan dan kehebatan Menteri Terawan yang nyatanya sampai saat ini belum beres menangani pandemi. Jika memang benar-benar hebat, seharusnya pandemi sudah berhasil ditangani, akan tetapi yang terjadi adalah sebaliknya, data menunjukkan jumlah paparan virus covid-19 makin tidak terkendali, artinya kehebatan yang dimaksud dalam konteks ini hanyalah sebuah "nama". Tidak terbuktikan. Tentu ini menjadi bentuk protes masyarakat yang diwakili Najwa Shihab kepada Menteri Terawan selaku Menteri Kesehatan RI sebagai pengendali utama pandemi. Sebab, sama dengan negara-negara lain, menteri kesehatanlah yang memegang kemudi dan (harusnya) paling sering muncul di hadapan publik memberi penjelasan, namun sayangnya ini sangat tidak sesuai dengan yang terjadi di Indonesia.

Penggunaan majas ironi dalam tuturan Najwa Shihab agaknya memang digunakan untuk memancing respons Menteri Kesehatan RI. Alasan ia jarang muncul 
akan menjadi daya tarik kuat yang ditunggu-tunggu oleh penonton acara Mata Najwa. Pemakaian majas sindiran yang halus ini digunakan untuk menggaet simpati para penonton dan memunculkan suasana tegang di tengah-tengah studio agar lambat laun penonton makin menanti-nanti pertanyaan-pertanyaan lain yang jauh lebih "tajam".

\section{Pertanyaan 2 (Majas Paradoks)}

"Pak Terawan, sampaisekarangkondisipandemibelum juga terkendali. Data dan angkajelasmenunjukkanitu. Disaat negara-negara lain bahkansudahberangsurangsurbisamemperlonggarsituasi, Pak. Kenapakitatertinggal?"'(1.41-1.51)

Dari pertanyaan di atas jelas terlihat bahwa ada penerapan majas paradoks di dalamnya. Majas paradoks diartikan sebagai majas yang mengandung pertentangan antara pernyataan dan fakta yang ada (Santoso, 2016). Dalam konteks pertanyaan di atas, yang dimaksud pernyataan diwakili oleh penggalan kalimat berikut, "negara lain bahkan sudah berangsur-angsur bisa memperlonggar." Artinya, negara-negara lain (bukan Indonesia) telah berhasil menangani wabah pandemi covid-19 dengan dibuktikan melonggarnya aturan untuk PSBB (Pembatasan Sosial Berskala Besar) atau juga dikenal dengan istilah lockdown. Dengan demikian, negara-negara lain ini sebenanrnya telah mengalami angka penurunan kematian/paparan virus covid-19 sehingga aturan untuk pembatasan sosial menjadi diperlonggar. Tentu adanya penurunan angka paparan covid-19 adalah gol yang dituju oleh semua negara, dan menjadi prioritas di tangan Menteri Kesehatan masingmasing negara, tidak terkecuali Indonesia. Lalu mengapa bisa terjadi, saat negara lain mengalami penurunan angka paparan covid-19, justru di Indonesia makin meningkat? Tentu, ini menjadi sorotan masyarakat luas, terlebih lagi Menteri Kesehatan sebagai pemegang kendali pasti dimintai pertanggungjawabannya. Pertentangan ini sedikit banyak disebabkan oleh kurang efektifnya kebijakan-kebijakan yang diterapkan oleh Menteri Terawan dalam hal penanganan covid-19. Dari uraian di atas, dapat diketahui bahwa ada hubungan pertentangan dengan objek yang dicontohkan yakni "kondisi negara lain semakin longgar" dan "Indonesia tertinggal". Pada dasarnya, penggunaan majas pertentangan pada pertanyaan ini berfungsi untuk memberi penekanan kepada Menteri Terawan, bahwa pembandingan antara Indonesia dan negara lain tidak sejalan. Saat negara lain mulai longgar, Indonesia justru tertinggal. Pertentangan ini sedikit banyak disebabkan oleh kurang efektifnya kebijakan-kebijakan yang diterapkan oleh Menteri Terawan dalam hal penanganan covid-19. Dari uraian di atas, dapat diketahui bahwa ada hubungan pertentangan dengan objek yang dicontohkan yakni "kondisi negara lain semakin longgar" dan "Indonesia tertinggal". Pada dasarnya, penggunaan majas pertentangan pada pertanyaan ini berfungsi untuk memberi penekanan kepada Menteri Terawan, bahwa pembandingan antara Indonesia dan negara lain tidak sejalan. Saat negara lain mulai longgar, Indonesia justru tertinggal.

\section{T2 : Disaat negara-negara lain bahkan sudah berangsur-angsur bisa memperlonggar situasi, Pak. Kenapa kita tertinggal?}

\section{K1 : Pak Terawan, sampai sekarang kondisi pandemi belum juga terkendali.}


Tuturan 2 diwakili oleh dua kata kunci, yakni "memperlonggar" dan "tertinggal". Tanpa melibatkan konteks, sebenarnya kedua kata ini sudah menunjukkan adanya pertentangan antara dua subjek, negara Indonesia dan negara lain (yang terkena covid-19 dan berhasil survive). Perbedaan dua situasi di dua negara berbeda ini diwakili oleh majas paradoks, yang mempertentangkan pernyataan dan fakta yang ada (Santoso, 2016). Majas paradoks dipakai oleh Mata Najwa untuk memperkuat ketajaman pertanyaan agar penonton semakin tercengang dengan fakta-fakta yang disampaikan Najwa sehingaa seolah-olah Indonesia ini benar-benar sangat tertinggal jauh, yang diwakili oleh kata "belum terkendali" pada konteks 1.

\section{Pertanyaan 3 (Majas Repetisi)}

"Presiden Jokowi secara terbuka berulang kali menegur kinerja anda di depan publik. Berangkat dari penilaian atasan anda itu, saya akan beri anda kesempatan untuk menjelaskan soal teguran itu satu per satu, Pak Menteri. Kenapa tes kita belum mencapai target? Kenapa resapan anggaran kementerian masih rendah? Kenapa berbagai peraturan dan birokrasi masih berbelit di kementerian kesehatan? Dan kenapa perlindungan tenaga kesehatan kita belum maksimal?" $(1.55-2.21)$

Dibandingkan dengan tuturan 1 dan 2, tuturan ketiga ini, agaknya menjadi pertanyaan paling panjang. Sebab, dalam satu pertanyaan ini, muncul anak-anak pertanyaan lain. Sehingga apabila dijumlah dengan seksama, ditemukan total empat pertanyaan dalam satu kali tempo tanya. Kemunculan anak-anak pertanyaan ini diikuti dengan kemunculan majas repetisi. Majas repetisi pada pertanyaan tiga ini ditandai dengan adanya kata "kenapa". Jelas bahwa keempat anak pertanyaan tersebut selalu diawali dengan kata tanya "kenapa". Kata tanya "kenapa" merupakan kata tanya yang jawabannya selalu diawali dengan kata "sebab/karena", sehinggan pertanyaan ini merupakan pertanyaan yang berfungsi untuk meminta penjelasan mengenai alasan mengapa sesuatu bisa terjadi. Pada anak pertanyaan 1, yakni "Kenapa tes kita belum mencapai target?", dimaksudkan untuk meminta alasan mengapa tes covid-19 di Indonesia masih belum memenuhi target yang ditetapkan. Padahal jumlah nakes, pengadaan alat tes telah dikeluarkan dengan cepat guna menananggulangi penyebaran wabah. Namun, dalam pelaksanaannya, tes masih belum mencapai sasaran $100 \%$, sehingga otomatis ini akan semakin memperlambat proses penanganan. Semakin lama tes dilakukan, penanganannya pun akan ikut molor. Tanpa tes, penyebaran virus tidak bisa diketahui. Oleh karena itu, target tes perlu dilakukan dicapai targetnyan dalam waktu secepat-cepatnya. Selanjutnya, pada anak pertanyaan kedua, yakni "Kenapa resapan anggaran kementerian masih rendah?", dimaksudkan untuk meminta penjelasan mengenai resapan dana di Kemenkes yang rendah, padahal Kemenkes sedang mengalami problem yang pelik dan harusnya pandemi ini merupakan problem utama negara, dengan demikian anggaran negara tentu saja akan lebih banyak lari kepada Kemenkes untuk penanggulangan pandemi, namun faktanya, justru anggaran Kemenkes lebih rendah dibanding anggaran Kementerian lain. Hal itu sangat patut dipertanyakan. Apakah pandemi di Indonesia ini tidak menjadi prioritas negara? Resapan anggaran rendah di Kemenkes juga turut membuktikan bahwa tidak banyak pergerakan yang dilakukan di kementeriaan di bawah naungan Menteri Terawan itu. Padahal yang menjadi motor penggerak di masa pandemi, haruslah 
Kementerian Kesehatan. Lalu, jika tidak ada pergerakan di Kemenkes, sampai kapan pandemi bisa diatasi? Pada anak pertanyaan ketiga, yakni "Kenapa berbagai peraturan dan birokrasi masih berbelit di kementerian kesehatan?", anak pertanyaan ini sebenarnya juga menyinggung anak pertanyaan satu dan dua, yang masih sama-sama berhubungan. Bisa jadi, apa yang ditanyakan di anak pertanyaan ketiga inilah yang turut menjadi penyebab mengapa belum tercapainya target tes covid-19 (anak pertanyaan satu), dan resapan anggaran Kemenkes yang rendah (anak pertanyaan ke-2). Sejak dulu sudah cukup dikenal bahwa birokrasi di Indonesia berbelit-belit, namun apakah masih tetap demikian jika di masa pandemi? Tentu pemerintah harus dengan cepat dan tanggap terhadap terobosanterobosan baru yang tercipta akibat pandemi, apalagi ini di tubuh Kementerian Kesehatan. Birokrasi dan aturan yang berbelit-belit akan membuat pandemi terus berlarut-larut disebabkan aturan yang tidak runut. Semuanya serba "mbulet", sehingga menghabiskan waktu lebih banyak, dan pada akhirnya waktu untuk menanggulangi pandemi jadi tidak tersisa. Di anak pertanyaan ke empat, "Kenapa perlindungan tenaga kesehatan kita belum maksimal? Tentu ini menjadi pertanyaan besar yang sangat mengganggu. Bagaimana tidak, jika tenaga kesehatan yang dianggap sebagai garda terdepan penyelamat pasien dari covid-19 tidak dilindungi dengan maksimal, lalu siapa yang mau "berkorban"? Ketidakmaksimalan pemerintah dalam melindungi tenaga kesehatan dibuktikan dengan jumlah nakes yang gugur cukup banyak. Dikutip dari www.kompas.com yang diakses pada tanggal 10 Januari 2020, Menurut catatan Laporan Satuan Gugus Tugas COVID-19, hingga 28 Desember 2020, total ada 507 nakes dari 29 provinsi di Indonesia yang telah gugur karena covid-19. Sebanyak 96 orang di antaranya meninggal dunia pada Desember 2020, dan merupakan angka kematian nakes tertinggi dalam sebulan selama pandemi berlangsung di tanah air. Ini semakin menjadi pembuktian ketidakbecusan pemerintah dalam menanggulangi wabah covid-19. Keempat anak pertanyaan di atas merupakan pertanyaan pelik yang harus dijawab sejelas-jelasnya sebab klarifikasi tentang ini menjadi hal yang ditunggu-tunggu masyarakat. Semakin tidak dijawab, masyarakat juga semakin bingung dan bisa jadi akan abai terhadap pandemi ini. Oleh karenanya, kejelasan sangat dibutuhkan.

\section{T3 : Kenapa tes kita belum mencapai target? Kenapa resapan anggaran kementerian masih rendah? Kenapa berbagai peraturan dan birokrasi masih berbelit di kementerian kesehatan? Dan kenapa perlindungan tenaga kesehatan kita belum maksimal?}

Tanpa kehadiran konteks, sebenarnya tuturan ketiga sudah bisa menunjukkan identitas dirinya sebagai bentuk pengungkapan melalui majas repetisi. Tuturan ketiga ini (yang mengandung empat anak pertanyaan) menjadi pertanyaan yang tajam karena ada pengulangan kata-kata yang dalam bahasa disebut majas repetisi. Menurut Widianto (2013), majas repetisi terdiri atas tiga varian, repetisi pengulangan kata; repetisi pengulangan pada tempat kata; repetisi pengulangan makna kata. Repetisi pada pertanyaan ini termasuk dalam repetisi variasi pengulangan kata, yang ditunjukkan denga kehadiran kata "kenapa" sebanyak empat kali. Pengulangan ini berfungsi untuk memberikan penegasan, agar makna yang dimunculkan bisa diketahui kefokusannya. Itulah yang menjadi alasan utama bagi Najwa Shihab agar penonton bisa menyimak lebih detail masalah-masalah apa saja yang terkait dengan pandemi covid-19 yang belum terselesaikan di Indonesia, tentu ini diharapkan dapat memperoleh jawaban yang 
memuaskan, akan tetapi sungguh sangat disayangkan, Menteri Terawan belum bisa menjawabnya.

\section{Pertanyaan 4 (Majas Alegori)}

"Masih saja ada disparitas antara data pusat dan data daerah, padahal data saat pandemi sangat krusial untuk menentukan kebijakan. Mengapa sampai sekarang juga tidak beres?" (2.39-2.47)

Untuk mengetahui secara riil tentang apa yang menjadi penyebab disparitas data covid-19 antara pusat dan daerah masih perlu dikaji lebih dalam, dan tentu saja yang bisa menjawab hal ini lebih jelas adalah Kementeriaan Kesehatan di bawah kendali Menteri Terawan. Kesenjangan data ini bisa jadi disebabkan oleh banyak hal. Akan tetapi satu hal yang pasti, adanya virus covid-19, telah mempertontonkan bahwa ada lubang dan jurang di dalam pelayanan kesehatan di banyak negara, tak terkecuali Indonesia (Djoerban, dkk. Ketua Satuan Gugus Tugas IDI untuk Covid-19). Ini menjadi bukti lemahnya bidang kesehatan di Indonesia dalam menanggulangi covid-19, termasuk pemberian perlindungan tenaga kesehatannya. Dari pertanyaan ini diketahui adanya perbandingan antara data pusat dan daerah yang mengalami kesenjangan, sehingga keduanya tidak sama. Perbandingan ini menunjukkan adanya penggunaan majas Alegori, yakni membandingkan dua atau lebih objek yang saling bertautan dan membentuk kesatuan yang utuh (Santoso, 2016).

\section{T4 : Masih saja ada disparitas antara data pusat dan data daerah.}

$\mathrm{K} 1$ : ....padahal data saat pandemi sangat krusial untuk menentukan kebijakan. Mengapa sampai sekarang juga tidak beres?

Majas alegori digunakan dalam kutipan di atas yang bertujuan untuk menunjukkan pertautan antara data pusat dan daerah yang tidak sinkron. Padahal keduanya sangat berguna, utamanya dalam menentuka kebijakan dan keputusan. Pertanyaan ini membandingkan objek data pusat dengan data daerah yang keduanya saling bertautan, saling memberi pengaruh terhadap pengambilan kebijakan terkait pandemi. Jadi apabila keduanya tidak berjalan seimbang, maka bisa jadi pengambilan kebijakan akan keliru karena tidak mempertimbangkan data-data yang akurat. Oleh karena di dalam pertanyaan ini perlu diketahui alasan mengapa masih ada disparitas antara keduanya. Tentu adanya disparitas ini, pada akhirnya akan membuat masalah pandemi tidak berhenti. Majas ini menyatakan perbandingan untuk meningkatkan kesan dan juga pengaruhnya terhadap pendengar dan pembaca (Zaim, 2014), yang pada kasus ini penonton acara Mata Najwa menjadi paham mengenai penyebab ketidakberesan pandemi yang salah satunya disebabkan oleh kebijakan yang tidak tepat karena dampak dari adanya disparitas data pusat dan daerah.

\section{Pertanyaan 5 (Majas Sinisme)}

"Pak Terawan ada banyak menteri kesehatan yang mundur karena penanganan covid19 misalnya menteri kesehatan New Zealand, Ceko, Polandia, Brazil, Chile, Pakistan, Israel publik health director-nya mundur, Canada publik health agency president-nya 
mundur. Pertanyaan saya pak, apakah penanganan kita lebih baik dari negara yang menkesnya mundur itu?" (3.06-3.26)

Agaknya pertanyaan kelima ini merupakan pertanyaan yang cukup mematikan. Sayangnya, karena ketidakhadiran narasumber, maka penonton tidak bisa menyaksikan bagaimana ekspresi narasumber ketika mendengar pertanyaan semacam ini. Pendengar pertanyaan ini tentu sudah mampu menyimpulkan dengan cepat majas apa yang sebenarnya terkandung pada pertanyaan ini. Yap. Tentu saja, pertanyaan ini mengandung majas sindiran, namun bukan majas ironi, seperti yang dikandung pertanyaan satu karena masih ada penggunaan kata-kata positif, akan tetapi, sebaliknya, dalam pertanyaan kelima ini, kata-kata positif sudah tidak digunakan, dan sindiran mulai ditampakkan secara terang-terangan. Majas yang menyatakan sindiran dengan terang - terangan disebut majas sinisme (Rani, 2018). Jika diklasifikasi, majas sinisme ini ada pada setingkat lebih tinggi di atas majas ironi, dan setingkat lebih rendah, di bawah majas sarkasme (yang menggunakan kata-kata kasar dalam pengungkapannya). Pertanyaan ini diawali dengan sebuah pernyataan kalimat berita yang menceritakan tentang kisah beberapa menteri kesehatan negara-negara lain yang muncul karena merasa tidak mampu menanggulangi pandemi dengan baik. Setidaknya, ada delapan negara yang harus menerima kemunduran menteri kesehatannya di tengah-tengah pandemi. Kedelapan negara itu adalah New Zealand, Polandia, Brazil, Chile, Pakistan, Israel, Columbia, dan Canada. Setelah menerangkan kedelapan negara yang Menkesnya mundur itu, kemudian dengan lantang, Najwa Shihab melanjutkan pertanyaan, apakah Indonesia penanganannya lebih baik dibandingkan dengan negara yang menkesnya mundur itu? Tentu kalimat pertanyaan ini seolah menjadi tamparan. Mengingat saat ini, kedelapan negara tersebut mulai berangsur-angsur membaik dan melonggarkan kebijakan terkait pandemi, meskipun penanganannya dianggap tidak baik yang berujung pada kemunduran Menteri Kesehatannya. Yang menarik, di Indonesia, meskipun jumlah dan data covid-19 makin tidak terkendali, dan dengan sejumlah masalah lain yang masih berkaitan dengan covid-19 yang justru sangat pelik, tetapi menteri kesehatannya masih bertahta di kursinya, ini memunculkan pertanyaan, apakah memang penanganan pandemi MenKes RI, Terawan Agus Putranto lebih bagus dibanding dengan kedelapan negara tersebut? Karena, jika tidak bagus, maka Menteri Terawan akan mundur. Jika tidak mundur, berarti bagus. Semacam itulah analogi sindiran yang dimunculkan oleh Najwa Shihab melalui pertanyaannya. Sindiran ini jelas dilakukan di depan publik, namun Menteri Terawan masih belum menjawab tentang tantangan ini (karena tidak hadir).

Jika digambarkan dalam tabel, kelima pertanyaan yang dilontarkan Najwa Shihab kepada Menteri Kesehatan, Terawan Agus Putranto berisi majas yang bervariasi. Kelimanya bias disimak melalui tabel 2 berikut. 
Undiksha| DOI: http://dx.doi.org/10.23887/prasi.v16i01.31537 | https://ejournal.undiksha.ac.id/index.php/PRASI

Tabel 2. Majas dalam Tuturan Najwa Shihab

\begin{tabular}{|c|c|c|}
\hline No & Pertanyaan & $\begin{array}{c}\text { Jenis Majas yang } \\
\text { Ditemukan }\end{array}$ \\
\hline 1 & $\begin{array}{l}\text { Pertanyaan } 1 \\
\text { "Mengapa menghilang, Pak? Anda minim sekali muncul } \\
\text { di depan publik memberikan penjelasan selama } \\
\text { pandemi. Rasanya menteri kesehatan paling low profile } \\
\text { di seluruh dunia selama wabah ini hanya menteri } \\
\text { kesehatan republik indonesia?" }(1.00-1.11)\end{array}$ & Majas ironi \\
\hline 2 & $\begin{array}{l}\text { Pertanyaan } 2 \\
\text { "Pak Terawan, sampai sekarang kondisi pandemi belum } \\
\text { juga terkendali. Data dan angka jelas menunjukkan itu. } \\
\text { Disaat negara-negara lain bahkan sudah berangsur- } \\
\text { angsur bisa memperlonggar situasi, Pak. Kenapa kita } \\
\text { tertinggal?”(1.41-1.51) }\end{array}$ & Majas Paradoks \\
\hline 3 & $\begin{array}{l}\text { Pertanyaan } 3 \\
\text { "Presiden Jokowi secara terbuka berulang kali menegur } \\
\text { kinerja anda di depan publik. Berangkat dari penilaian } \\
\text { atasan anda itu, saya akan beri anda kesempatan untuk } \\
\text { menjelaskan soal teguran itu satu per satu, Pak Menteri. } \\
\text { Kenapa tes kita belum mencapai target? Kenapa } \\
\text { resapan anggaran kementerian masih rendah? Kenapa } \\
\text { berbagai peraturan dan birokrasi masih berbelit di } \\
\text { kementerian kesehatan? Dan kenapa perlindungan } \\
\text { tenaga kesehatan kita belum maksimal?" (1.55-2.21) }\end{array}$ & Majas Repetisi \\
\hline 4 & $\begin{array}{l}\text { Pertanyaan } 4 \\
\text { "Masih saja ada disparitas antara data pusat dan data } \\
\text { daerah, padahal data saat pandemi sangat krusial untuk } \\
\text { menentukan kebijakan. Mengapa sampai sekarang juga } \\
\text { tidak beres?" (2.39-2.47) }\end{array}$ & Majas Alegori \\
\hline 5 & $\begin{array}{l}\text { Pertanyaan } 5 \\
\text { "Pak Terawan ada banyak menteri kesehatan yang } \\
\text { mundur karena penanganan covid-19 misalnya menteri } \\
\text { kesehatan New Zealand, Ceko, Polandia, Brazil, Chile, } \\
\text { Pakistan, Israel publik health director-nya mundur, } \\
\text { canada publik health agency president-nya mundur. } \\
\text { Pertanyaan saya pak, apakah penanganan kita lebih } \\
\text { baik dari negara yang menkesnya mundur itu?" }(3.06-\end{array}$ & Majas Sinisme \\
\hline
\end{tabular}

Berdasarkan hasil penelitian tersebut, diketahui bahwa pertanyaan-pertanyaan yang dilontarkan pemandu acara talkshow Mata Najwa, Najwa Shihab kepada Menteri Kesehatan, Terawan Agus Putranto dalam episode \#MataNajwaMenantiTerawan mengandung majas yang bervariasi, yakni majas ironi, repetisi, paradoks, alegori, dan sinisme. Dari kelimanya, bisa disimpulkan bahwa majas perbandinganlah yang mendominasi pertanyaan-pertanyaan Najwa Shihab. Penggunaan majas perbandingan yang mendominasi tuturan Najwa Shihab tentu selaras dengan tujuan yang ingin 
disampaikan yakni untuk menyindir lawan bicaranya, dalam hal ini adalah Menteri Kesehatan RI, Terawan Agus Putranto. Majas ini juga bertujuan untuk mengubah perilaku seseorang sebagai wujud dari dampak yang ditimbulkan akibat dari sindiran tersebut. Lebih luas daripada itu, penggunaan majas sindiran juga berpotensi untuk memunculkan suasana ketegangan selama acara dan menjadi daya tarik tinggi untuk menggaet simpati penonton karena keberanian dan ketajaman pertanyaan-pertanyaan Najwa Shihab sehingga acara Mata Najwa menjadi primadona masyarakat/penonton televisi.

\section{SIMPULAN}

Berdasarkan penelitian yang dilakukan peneliti tentang analisis majas dalam acara talkshow Mata Najwa episode \#MataNajwaMenantiTerawan dapat ditarik kesimpulan bahwapertanyaan-pertanyaan yang dilontarkan pemandu acara talkshow Mata Najwa, Najwa Shihab kepada Menteri Kesehatan, Terawan Agus Putranto dalam episode \#MataNajwaMenantiTerawan mengandung majas yang bervariasi, yakni majas ironi, repetisi, paradoks, alegori, dan sinisme. Dari kelima majas yang ditemukan, bisa disimpulkan bahwa majas perbandinganlah yang mendominasi pertanyaan-pertanyaan Najwa Shihab. Penggunaan majas perbandingan yang mendominasi tuturan Najwa Shihab tentu selaras dengan tujuan yang ingin disampaikan yakni untuk menyindir lawan bicaranya, dalam hal ini adalah Menteri Kesehatan RI, Terawan Agus Putranto. Majas ini juga bertujuan untuk mengubah perilaku seseorang sebagai wujud dari dampak yang ditimbulkan akibat dari sindiran tersebut. Lebih luas daripada itu, penggunaan majas sindiran juga berpotensi untuk memunculkan suasana ketegangan selama acara dan menjadi daya tarik tinggi untuk menggaet simpati penonton karena keberanian dan ketajaman pertanyaan-pertanyaan Najwa Shihab sehingga acara Mata Najwa menjadi diminati khalayak.

\section{DAFTAR PUSTAKA}

Adiba, F. (2018). Makna Kontekstual Meme Humor Pada Media Sosial Instagram Dalam Fanspage Meme Comic Indonesia (Mci) Edisi Januari-Februari.Jurnal Pendidikan Bahasa Dan Sastra Indonesia Metalingua. https://doi.org/ 10.21107/metalingua.v3i1.7025

Afrizal. (2016). Metode Penelitian Kualitatif, Sebuah Upaya Mendukung Penggunaan Penelitian Kualitatif Dalam Berbagai Disiplin Ilmu. In Jakarta: PT RajaGrafindo Persada.

Anggraini, W. R., Sumantri, D. A., Purnomo, S. I., \& Anggraini, P. (2019). Pengembangan Media Pembelajaran Majas Berbasis Teknologi. Deiksis: Jurnal Pendidikan Bahasa Dan Sastra Indonesia. https://doi.org/ 10.33603/deiksis.v6i1.1322

Kartikasari, R. D. (2016). Ragam Bahasa Pedagang Kaki Lima di Terminal Purbaya Surabaya : Kajian Sosiolinguistik. Buana Bastra. 


\section{PRASI UNRNL BAHASA, SEN, DAN PENGAARANWA}

VOL. 16 | No. 01 | Juni 2021

ISSN: Print 1693-6124 - Online 2614-1116

Undiksha| DOI: http://dx.doi.org/10.23887/prasi.v16i01.31537 | https://ejournal.undiksha.ac.id/index.php/PRASI

Kayati, A. N. (2020). Struktur Tuturan Adu Mulut Farhat Abas Dengan Dewi Persik Dalam Acara Hitam Putih.Jurnal Pendidikan Bahasa Dan Sastra Indonesia Metalingua. https://doi.org/10.21107/metalingua.v5i1.7046

Muamanah, S., Lastri, L., \& Nofiyanti, N. (2019). Analisis Majas Pada Lirik Lagu Tulus Yang Berjudul Pamit Dan Sepatu. Parole (Jurnal Pendidikan Bahasa Dan Sastra Indonesia).

Ningsih, T., Nuryanti, M., \& Mutaqin, D. (2019). Analisis Kebahasaan Teks Editorial pada Harian Pikiran Rakyat Edisi 2017 sebagai Pengembangan Materi Ajar Teks Editorial SMA Kelas XII.Jurnal Pendidikan Bahasa Dan Sastra Indonesia Metalingua. https://doi.org/10.21107/metalingua.v4i1.6121

Nurgiyantoro, B. (2015). Stile dan Stilistika.Diksi. https://doi.org/10.21831/diksi. v0i1.7100

Rani. (2018). Penggunaan Majas Sindiran dalam Pembelajaran Bahasa Indonesia Siswa Kelas IX SMP Negeri 1 Balaesang Desa Tambu Kecamatan Balaesang Kabupaten Donggala. Jurnal Bahasa Dan Sastra.

Santoso, S. (2016). Majas dalam Novel Semesta Mendukung Karya Ayuwidya. Jurnal Bastra.

Zaim, M. (2014). Metode Penelitian Bahasa: Pendekatan Struktural. 1-161.

Zaimar, O. K. S. (2002). Majas Dan Pembentukannya. Makara Human Behavior Studies in Asia. https://doi.org/10.7454/mssh.v6i2.38 